\title{
Fatty Acid Composition in Yersinia ruckeri Strains Isolated from Rainbow Trout Farms
}

\section{Ünal İSPIR ${ }^{1}$, Mikail ÖZCAN2 ${ }^{2}$, Muammer KIRICI ${ }^{3}$}

${ }^{1}$ Malatya Turgut Ozal University, Doğanşehir Vahap Küçük Vocational School, Department of Aquaculture, Malatya, Turkey, ${ }^{2}$ Kahramanmaras Sutcu Imam University, Agriculture Faculty, Department of Fisheries Kahramanmaras, Turkey, ${ }^{3}$ Bingol University, Food Agriculture and Livestock Vocational School, Department of Veterinary Health, Bingöl, Turkey.

1https://orcid.org/0000-0002-2077-0219, ${ }^{2} \mathrm{https://orcid.org/0000-0001-9032-0697,}{ }^{3} \mathrm{https} / / /$ orcid.org/0000-0003-1888-4388

$\triangle$ : mikailozcan@ksu.edu.tr

\begin{abstract}
In this study, a total of 33 Yersinia ruckeri isolates were obtained from rainbow trout farms in the five different region of Turkey. We determined to changes in fatty acids group of the strains. All the isolates were identified as $Y$. ruckeri based on colonical, cellular morphology and biochemical characters. All Y. ruckeri 8 major fatty acids, including 12:0 (Lauric acid), 14:0 (Myristic acid), 16:0 (Palmitic acid), 16:1n-7 (Palmitoleic acid), 17:1 (Heptadecanoic acid), 18:1n-9c (Oleic acid), 18:2n-6c (Linoleic acid), 18:3n-3c (Alfa-linoleic acid). Compared to isolates biochemical property, there was no difference between fatty acids and biochemical characteristics. The results of this study showed that the fatty acids composition of $Y$. ruckeri isolated strains from rainbow trout farms in Turkey is on a large scale homogenous.
\end{abstract}

Research Article

$\begin{array}{ll}\text { Article History } & \\ \text { Received } & : 09.12 .2020 \\ \text { Accepted } & : 26.03 .2021\end{array}$

Keywords

Rainbow trout

Yersinia ruckeri

Fatty acids composition

\section{Gökkuşağı Alabalığı Yetiştiricilik Tesislerinden Izole Edilen Yersinia Ruckeri Suşlarının Yağ Asit} Kompozisyonu
ÖZET
Bu çalışmada Türkiye'nin beş farklı bölgesindeki gökkuşağı alabalığı yetiştiricilik tesislerinden izole edilen 33 Yersinia ruckeri yağ asit miktarlarındaki değişimler incelenmiştir. Bütün suşların koloni ve hücre morfolojisi ile biyokimyasal özellikleri yönünden incelenmesi sonucu $Y$. ruckeri olduğu ortaya konulmuştur. Bütün $Y$. ruckeri suşlarında 12:0 (Laurik asit), 14:0 (Miristik asit), 16:0 (Palmitik asit), 16:1n-7 (Palmitoleik asit), 17:1 (Heptadekanoik asit), 18:1n-9c (Oleik asit), 18:2n-6c (Linoleik asit), 18:3n-3c (Alfa-linoleik asit) gibi 8 önemli yağ asidi tespit edilmiştir. İzolatların biyokimyasal özellikleri karşılaştırılmıştır. Yağ asidi ve biyokimyasal özellikler arasında farklılık bulunamamıştır. Bu çalışmada Türkiye'deki gökkuşağı alabalığı yetiştiricilik tesislerinden izole edilen $Y$. ruckeri suşlarının yă̆ asidi kompozisyonunun büyük oranda homojen olduğu görülmüştür.

\section{Araştırma Makalesi}

Makale Tarihçesi

Geliş Tarihi : 09.12 .2020

Kabul Tarihi : 26.03.2021

\section{Anahtar Kelimeler}

Gökkuşağı alabalığı

Yersinia ruckeri

Yağ asidi kompozisyonu

To Cite : İspir Ü, Özcan M, Kırıcı M 2021. Fatty Acid Composition in Yersinia ruckeri Strains Isolated from Rainbow Trout Farms. KSU J. Agric Nat 24 (6): 1208-1211. DOI: 10.18016/ksutarimdoga.vi.838056.

\section{INTRODUCTION}

Enteric red mouth disease, known as ERM or Yersiniosis, was first reported in 1950's in the rainbow trout farms in the USA as a septicemic disease with high mortality rates in sub-acute and acute forms (Bullock and Anderson, 1984; Busch, 1982; Frerichs and Roberts, 1989; Lucangeli et al., 2000; Ross et al., 1966). ERM disease is widespread in many parts of the world (Bullock et al., 1977; Roberts, 1983; Lesel et al., 1983; Stevenson and Daly, 1982).

In Turkey, Yersiniosis caused by Yersinia ruckeri was identified in rainbow trouts in 1991. As the trout farms increased in number, the disease became more widespread, starting to cause economic losses. This disease is currently frequently found in trout farms and has become the most important bacterial disease in Turkey (Çağırgan and Yüreklitürk, 1991; Kubilay, 1997; Kubilay and Diler, 1999; Timur and Timur, 1991).

A standartdized and rapid identification system is offered by the API 20E system. Miniaturized multitest system was originally developed for the identification of Gram-negative enteric bacteria in clinical laboratories. During the last decade, this system has been increasingly used for the identification of marine 
and fresh water fish pathogens (Tanrıkul et al., 2004).

Lipids are one of the most basic organic compounds in bacteria, as in other living things in the world. Lipids, which play an important role in the functions of cytoplasmic membranes, are affected by different environmental factors such as temperature, surface tension, osmotic pressure and $\mathrm{pH}$. Fatty acids that make up lipids in defining and characterizing bacteria are accepted as one of the basic taxonomic criteria. It is considered that free fatty acid complexes, which are used in bacterial systematics, will be a good chemotaxonomic property in different growth environments in terms of microbial ecology (Kariptas, 1999).

The detection of the fatty acids of the bacteria using gas chromatography dates back to the 1960s. It has been suggested that mobile Aeromonas strains of clinical and non-clinical origin can be classified by liquid-gas chromatography according to their fatty acid metal ester profiles (Canonica and Pisono, 1985).

In this study, the analysis of the heterogeneity of $Y$. ruckeri isolated from fish in the trout farming plants in different regions of Turkey was carried out in order to reveal their fatty acid profiles. For this purpose, the biochemical properties of the strains used in the study, in addition to the traditional biochemical tests, the relationship of epidemiological characters with the fatty acid composition were revealed.

\section{MATERIAL and METHODS}

\section{Bacteria}

Y. ruckeri (33) isolates used in the study were isolated from classical fish farms in different regions of Turkey between 2005 and 2014 by classical methods. All strains were cultured at $25^{\circ} \mathrm{C}$ using Tryptic Soy Agar (TSA). Isolates that were revealed to be $Y$. ruckeri by biochemical tests were confirmed using the Polymerase Chain Reaction (PCR) method reported by Şeker et al. (2012). Sowing was performed in ShottsWaltman Medium (SWM) and Ribose Ornitine Deoxycholate (ROD) selective fattening sites.

Isolates, which were previously isolated and added to glycerin in Triptic Strain Broth (TSB), kept at $-20^{\circ} \mathrm{C}$, were freshly cultured in Triptic Strain Agar (TSA) for sterility control before the study started, and it was checked whether the strains were pure. DSM18506 was used as the reference strain. Table 1 shows the geographical distribution of the isolates used in the study.

Table 1. The gathering places of $Y$. ruckeri used in the study

Cizelge 1. Calışmada kullanılan Y. ruckerinin toplanma yerleri

\begin{tabular}{llll}
\hline Isolate no & Collection date & Region-city & Organ-isolated location \\
\hline $1-6$ & 2005,2014 & Malatya & Kidney-lesion \\
7 & 2011 & Aydın & Kidney \\
8 & 2012 & Rize & $? ? ? ? ?$ \\
$9-10$ & 2008,2012 & Kayseri & Kidney \\
$11-23$ & $2005-2014$ & Elazığ & Kidney, spleen-lesion \\
24,25 & 2009 & Mersin & $? ? ? ? ?$ \\
$26-30$ & $? ? ? ? ?$ & Isparta & $? ? ? ? ?$ \\
31,32 & 2011 & Artvin & Liver \\
33 & 2010 & Muğla & Liver \\
\hline
\end{tabular}

\section{Fatty acid extraction and analysis}

Bacteria were incubated in $100 \mathrm{ml}$ TSB placed in $500 \mathrm{ml}$ flasks at $25{ }^{\circ} \mathrm{C}$ for 48 hours and collected by centrifugation at $2500 \mathrm{rpm}$ for 10 minutes. The bacteria were washed twice with $0.85 \% \mathrm{NaCl}$ and kept at room temperature for 2 hours. For hydrolysis of approximately $55 \mathrm{mg}$ bacteria biomass, $\mathrm{NaOH}$ and 1 $\mathrm{ml}$ of methanol mixture were added and incubated for 30 minutes in a water bath at $95^{\circ} \mathrm{C}$. Then, $2 \mathrm{ml}$ of $6 \mathrm{~N}$ $\mathrm{HCl}$ prepared in methanol was added to methylation of free fatty acids and kept for 10 minutes in a water bath at $80^{\circ} \mathrm{C}$. The aqueous phase for fatty acid extraction was collected and $1.15 \mathrm{ml}$ of the hexane/methyl tertbutyl ether (1:1) mixture was added to each tube and inverted for 10 minutes. After the supernatant was removed, $3 \mathrm{ml}$ of $1.2 \% \mathrm{NaOH}$ was added and shaken for 5 minutes. The supernatant organic phase was taken to the chromatography bottles (viallere) for fatty acid determination.

Fatty acid analysis was carried out by using Ultra 2HP (25m x 0,22 mm x 0,33mm) column and hydrogen gas in gas chromatography-mass spectrophotometer (GC-MS).

\section{RESULTS and DISCUSSION}

It was determined that $33 Y$. ruckeri isolates used in the study showed a homogeneous structure in terms of biochemical tests.

Results revealed that $Y$. ruckeri forms a ground glasslike zone due to the precipitation of calcium salts and hydrolysis of Tween 80 by forming green colored colonies in Shotts-Waltman medium (SWM) selective medium. Y. ruckeri was found to give yellow colonies in Ribose Ornitine Deoxycholate (ROD) medium as a result of fermentation of ribose and precipitation of sodium desoxycholate salts. The positive result of 
isolate 7 in terms of Sorbitol test is that this strain has serotype 2 characteristics. This strain was immobile and found that it did not hydrolyze the tween 80 .

It was determined that $Y$. ruckeri bacteria isolated from different regions of Turkey did not have a significant differences in fatty acid composition and had a homogeneous structure. The composition of bacterial isolates to fatty acid is shown in Table 2.8 . Important fatty acids such as 12:0 (Lauric acid), 14:0 (Myristic acid), 16:0 (Palmitic acid), 16:1n-7 (Palmitoleic acid), 17:1 (Heptadecanoic acid), 18:1n-9c (Oleic acid), 18:2n-6c (Linoleic acid), 18:3n-3c (Alfalinoleic acid) were detected in bacterial strains.

Table 2. Fatty acid levels of $Y$. ruckeri isolates.

Cizelge 2. Y. ruckeri izolatlarının yağ asit düzeyleri.

\begin{tabular}{|c|c|c|c|c|c|c|c|c|}
\hline \multicolumn{9}{|c|}{ Fatty acids (\%) } \\
\hline Isolates & $12: 0$ & $14: 0$ & $16: 0$ & $16: 1 n-7$ & $17: 1$ & $18: 1 n-9 c$ & $18: 2 n-6 c$ & $18: 3 n-3 c$ \\
\hline $1-6$ & 4.98 & 1.32 & 22.00 & 0.34 & 0.55 & 1.38 & 10.05 & 2.0 \\
\hline 7 & 4.99 & 0.97 & 24.95 & 1.02 & 1.09 & 1.41 & 12.45 & 2.59 \\
\hline 8 & 5.3 & 1.39 & 19.90 & 0.29 & 0.55 & 1.37 & 11.00 & 2.33 \\
\hline $9-10$ & 5.09 & 1.30 & 19.95 & 0.30 & 0.54 & 1.38 & 10.95 & 2.53 \\
\hline $11-23$ & 4.98 & 1.33 & 21.00 & 0.30 & 0.51 & 1.37 & 10.95 & 2.51 \\
\hline 24,25 & 5.06 & 1.40 & 21.53 & 0.32 & 0.51 & 1.36 & 11.00 & 2.71 \\
\hline $26-30$ & 5.12 & 1.42 & 19.89 & 0.32 & 0.55 & 1.36 & 11.02 & 2.65 \\
\hline 31,32 & 5.26 & 1.29 & 19.95 & 0.31 & 0.53 & 1.36 & 10.98 & 2.66 \\
\hline 33 & 4.99 & 1.29 & 19.99 & 0.31 & 0.53 & 1.37 & 9.42 & 2.68 \\
\hline DSM18506 & 5.21 & 1.41 & 21.04 & 0.32 & 0.54 & 1.36 & 10.55 & 2.69 \\
\hline
\end{tabular}

DSM18506: Yersinia ruckeri serotype O1 reference strain

Lipid compounds are abundant in the cell wall and cytoplasmic membrane of gram-negative microorganisms. Among the most common lipids are cylopropane acid in E.coli, palmitic acid, cis-vaccenic acid, beta-hydroxy myristic acid in endotoxin of E. coli, beta-hydroxy acid in $P$. aeruginosa, cis-vaccenic acid in Agrobacter tumefaciens, palmitic acid in S. marcescens and 9, 10-methylen hexadecanvic acid, even and unsaturated fatty acids in microplasms, cholesterol and a small amount of caprilic acid and capric acid (Arda, 2000). In this study Y. ruckeri strains, 11 important fatty acids were detected such as 12:0 (Laurik acid), 14:0 (Miristik acid), 16:0 (Palmitik acid), 16:1n-7 (Palmitoleik acid), 17:1 (Heptadekanoik acid), 18:1n-9c (Oleik acid), 18:2n-6c (Linoleik acid), 18:3n-3c (Alfa-linoleik acid).

Bacteria are the simplest and smallest microbial cells. Few of the bacteria with low oil production can synthesize the desired amount of oil (Denli and Tekin, 2000). Current information on the production of oil in bacteria is more related to pathogens. In the study conducted by Bunker (1963), Mycobacterium species stand out among the 5 microorganisms whose fat ratios vary between 7-21\%. In a recent study (Beopoulos et al., 2009), it is stated that the total cell mass of Rhodotorula glutinis can store $72 \%$ fat. In the same article, although it is a very rare condition among bacteria, it is stated that Rhodococcus opacus bacteria can form a very high fat accumulation as $87 \%$, but there is no information about the form of the oil. In this study, all of the samples are also pathogenic. Fat ratios obtained from samples range between $40.58 \%$ and $49.47 \%$ as with Malatya (1-6) $42.62 \%$; Aydın (7) 49.47\%; Rize (8) 42.13\%; Kayseri (9-10) 42.04\%; Elazı̆̆
(11-23) 42.95\%; Mersin (24-25) 43.89\%; Isparta (26-30) 42.33\%; Artvin (31-32) 42.34\%; Muğla (33) 40.58\%.

The examination of fatty acid profiles was performed on 33 Yersinia ruckeri species isolated from rainbow trout breeding facilities in 9 provinces in five different regions. As a result of gas chromatography analysis, fatty acid profile was determined as 12:0, 14:0, 16:0, $16: 1 \mathrm{n}-7,17: 1,18: 1 \mathrm{n}-9 \mathrm{c}, 18: 2 \mathrm{n}-6 \mathrm{c}, 18: 3 \mathrm{n}-3 \mathrm{c}$. When this results were compared to previous reports on FAME composition of $Y$. ruckeri isolates from the USA (Arias et al., 2007) and Fatty acid composition of Yersinia ruckeri isolates from aquaculture ponds in North West Germany (Huang et al., 2014), the fatty acids 12:0, 14:0 and 16:0 were found as main components in three studies. Jantzen and Lassen (1980) observed that strains from Yersinia pseudotuberculosis, Yersinia enterocolitica and Yersinia pestis all exhibited a similar fatty acid composition of 14:0, 16:1 and 16:0 and 16:0 was the most prominent fatty acid present in Yersinia pestis and Yersinia pseudotuberculosis (Tan et al., 2010). Canonica and Pisano (1988) reported in a study with Aeromonas species that they contain 12:0, 14:0, 15:0, 16:0, 17:0, 18:0, 16:1, 18:1, and $3-\mathrm{OH} 14: 0$ fatty acids. Fatty acid contents of 10 Bacteria species of Aeromonas species isolated from 52 ice cream samples taken from ice cream in Kirşehir were examined and it was determined as 12:0, 14:0, 15:0, 15:0 $3 \mathrm{OH}, 16: 1,16: 0$ ve 17:1, 17:0 3OH, 18:1 and 18:0 (Kariptaş and Yeniçeri, 2016). The fatty acid profile of $Y$. ruckeri obtained in this study with the fatty acid profiles determined as a result of studies with different species show (12:0, 14:0, 16:0 ve 17:1) similarities and $\left(16: 1 n^{-} 7,18: 1 n^{-} 9 c, 18: 2 n^{-} 6 c, 18: 3 n^{-} 3 c\right)$ differences. 


\section{CONCLUSION}

Results of this study cocluded that the fatty acid composition of $Y$. ruckeri strains isolated from rainbow trout farms in different geographic regions of Turkey revealed that $Y$. ruckeri strains sustain a very similar character in terms of fatty acid composition. It has been determined that serotype 1 strain is common in Turkey as in European countries. Since this research has been studied with $Y$. ruckeri strains isolated from businesses covering different geographic regions of Turkey, the results of the research obtained will contribute to future studies with this bacterium.

\section{Acknowledgment}

This work was presented as a oral presentation at the International Conference on Natural Science and Engineering (ICNASE'16), March 19-20, 2016, Kilis, Turkey.

\section{Researchers Contribution Rate Declaration Summary} The authors declare that they have contributed equally to the article.

\section{Conflicts of Interest Statement}

None of the authors had any financial or personal relationships with other individuals or organizations that might inappropriately influence their work during the submission process.

\section{REFERENCES}

Arda M 2000. Temel Mikrobiyoloji; Genişletilmiş İkinci Baskı. Medisan Yayın Serisi no 46. Ankara, $548 \mathrm{p}$.

Beopoulos A, Chardot T, Nicaud JM 2009. Yarrowia lipolytica: A model and a tool to understand the mechanisms implicated in lipid accumulation. Biochimie, 91(6): 692-696.

Bullock GL, Anderson DP 1984. Immunization Against Yersinia ruckeri, Cause and Enteric Redmouth Disease. (Symposium on fish Vaccination. Theoretical Background and Practical Results on Immunization Against Infectious Diseases). 20-22 February, O.T.E. PARIS. 66-151.

Bullock GL, Stuckey HM, Shotts EB 1977. Early Records of North American and australian outbreoks of enteric redmouth bacterium. Fish Health News, 6(2): 96-97.

Bunker HJ 1963. Microbial Food. Rainbow, C., Rose, A., H., (Ed.), Biochemistry of Industrial Microorganisms. Academic Press, 147. New York, 34-67 pp.

Busch RA 1982. Enteric Redmouth Disease. Symposium International de Talloires. 10-12 May., 1982, Les Antigenes des Microorganismes Pathogens des Poissons. Collection Fondation Marcel Merieux, 201-224.
Çagırgan H, Yüreklitürk O 1991. First isolation of Yersinia ruckeri from rainbow trout farm in Turkey, In: The Fifth Conference of EAFP, Disease of Fish and Shellfish, 24-29 August 1991, Book of Abstract, $131 \mathrm{p}$.

Canonica FP, Pisano MA 1985. Identification of hydroxy fatty acids in Aeromonas hydrophila, Aeromonas sobria, and Aeromonas caviae. Journal of Clinical Microbiology, 22(6): 1061-1062.

Canonica FP, Pisano MA 1988. Gas-Liquid Chromatographic Analysis of Fatty Acid Methyl Esters of Aeromonas hydrophila, Aeromonas sobria, and Aeromonas caviae. Journal of Clinical Microbiology, 26(4): 681-685.

Denli Y, Tekin A 2000. Oil production and microorganisms. Gida dergisi, 25(4): 265-270.

Frerichs GN, Roberts RJ 1989 The bacteriology of Teleosts. In: Fish patalogy (ROBERTS, R.J. ed.) Second Edition. Bailliere Tindall, London 289-320 pp.

Huang Y, Ryll M, Walker C, Jung A, Runge M, Steinhagen D 2013. Fatty acid composition of Yersinia ruckeri isolates from aquaculture ponds in North West Germany. Berliner und Munchener Tierarztliche Wochenschrift, 127(1-2):10-15.

Jantzen E, Lassen J 1980. Characterization of Yersinis species by analysis of whole-cell fatty acid. International Journal of Systematic Bacteriology, 30: 421-428.

Kariptas E 1999. Chemical Composition of Rhodococcus Ruber with Different Growth Conditions, PhD Thesis, University of Newcastle upon Tyne, England, 233 p.

Kariptaş E, Yeniçeri M 2016. A Study on the Antimicrobial Resistance and Fatty Acid Compositions of Motile Aeromonas Isolated From Ice Cream Samples in the City of Kirşehir (Turkey). Turkish Journal of Agricultural and Natural Sciences, 3(4): 318-323.

Kubilay A 1997. A Study on antibody production and detection in rainbow trout (Oncorhynchus mykiss) against pathogen Yersinia ruckeri. Süleyman Demirel University, Institute of Science, PhD Thesis, $118 \mathrm{p}$.

Kubilay A, Diler Ö 1999. Lam agglutination test and detection of serotypes of Yersinia ruckeri strains isolated from rainbow trout. Journal of Suleyman Demirel University Faculty of Fisheries, 6(1): 4047.

Lesel R, Lesel M, Gavini F, Vuillaume A 1983. Outbreak of enteric red mouth disease in rainbow trout, Salmo gairdneri richhardson, in France. Journal of Fish Diseases, 6: 385-387.

Lucangeli C, Morabito A, Caprioli A, Achene L, Busani L, Mazzolini E, Fabris A, Macri A 2000. Molecular fingerprinting of strains of Yersinia ruckeri serovar $\mathrm{O} 1$ and Photobacterium damsela subsp. piscicida isolated in Italy. Veterinary Microbiology, 76: 273- 
281.

Roberts MS 1983. A report of an epizootic in hatchery reared rainbow trout, Salmo gairdneri Richardson at an English trout from, caused by Yersinia ruckeri. Journal of Fish Diseases, 6: 551-552.

Ross AJ, Rucker RR, Ewing WN 1966. Description of a bacterium associated with remouth disease of rainbow trout. Canadian journal of Microbiology, 12: 763-770.

Şeker E, Karahan M, İspir Ü, Çetinkaya B, Sağlam N, Sarıeyyüpoğlu M 2012. Investigation of Yersinia ruckeri Infection in Rainbow Trout (Oncorhynchus mykiss Walbaum 1792) Farms by Polymerase Chain Reaction (PCR) and Bacteriological Culture. Kafkas Universitesi Veteriner Fakultesi Dergisi, 18(6): 913-916.

Stevenson RMW, Daly JG 1982. Biochemical and serological characteristic of Ontario isolates of Yersinia ruckeri. Canadian Journal of Fisheries and Aquatic Sciences, 39: 870-876.

Tan Y, Wu M, Liu H, Dong X, Guo Z, Song Z, Li Y, Cui Y, Song Y, Du Z, Yang R 2010. Cellular fatty acids as chemical markers for differentiation of Yersinia pestis and Yersinia Pseudotuberculosis. Lett Appl Microbiol 50: 104-111.

Tanrıkul TT, Çağırgan H, Tokşen E 2004. Identification of isolated Vibrio $s p$. from sea bass (Dicentrarchus labrax L., 1758) using API 20E system. E.U. Journal of Fisheries \& Aquatic Sciences, 22(3-4): 243-247.

Timur G, Timur M 1991. An Outbreak of Enteric redmouth disease in farmed rainbow trout (Onchorynchus mykiss) in Turkey. Bull. Bulletin of the European Association of Fish Pathologists, 11: 182-183. 